\title{
CPCs and ECM: A Good Mix for Cardiac Regeneration
}

\author{
Vittorio Picchio ${ }^{1}$, Tania Di Raimo ${ }^{2,3}$, Francesco Angelini ${ }^{2,3 *}$ \\ ${ }^{1}$ Department of Medical Surgical Sciences and Biotechnologies, "La Sapienza" \\ University of Rome, Latina 04100, Italy; \\ ${ }^{2}$ Centro Di Riferimento Oncologico-National Cancer Center, Experimental \& \\ Clinical Pharmacology, Aviano 33081, Italy; \\ ${ }^{3}$ Medical Oncology and Anatomic Pathology Unit, San Filippo Neri Hospital, \\ Rome 00135, Italy.
}

* Corresponding Author: Francesco Angelini. Email: francescoangelini01@gmail.com.

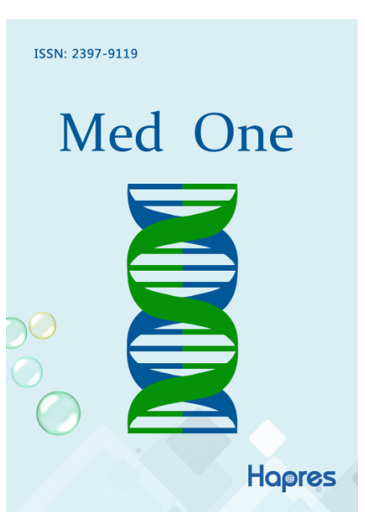

https://mo.hapres.com

\section{GOPEN ACCESS}

DOI: $10.20900 / \mathrm{mo} .20180014$

Received: November 12, 2018

Accepted: December 20, 2018

Published: December 27, 2018

Copyright: $\odot 2018$ by the authors. Licensee Hapres, London, United Kingdom. This is an open access article distributed under the terms and conditions of the Creative Commons Attribution License (CC BY 4.0, https://creativecommons.org/licenses/by/4.0/).

\begin{abstract}
Despite several improvements in term of diagnosis and prevention, ischemic heart disease still represents one of the principal worldwide causes of death. Cardiac progenitor cells (CPCs) based therapy is considered a valid alternative to heart transplant, but several issues concerning the transplanted cells viability, retention and therapeutic effect need to be solved. Tissue engineering, mixing synthetic or natural polymers with injected cells, could represent the way through which overcomes shortages and set up an effective cardiac regenerative therapy. Nowadays, it is well known that cardiac extracellular matrix (ECM) provides structural and functional integrity, affects cardiac function, development and physiologic repair. In this optic, ECM and ECM-like materials represent functional and biocompatible tools with a great potential to serve as natural or nature-mimicking scaffolds in the field of regenerative medicine. The aim of the present work is to provide an overview on the state of the art and recent advantages on CPCs and scaffold-based therapy for heart regeneration.
\end{abstract}

Keywords: cardiac progenitor cells; ECM; heart regeneration; tissue engineering; biomaterials

\section{INTRODUCTION}

Despite considerable achievements in term of early diagnosis and prevention, ischemic heart disease still represents the leading cause of death and disability worldwide and its frequency is increasing. In 2018, it has been established that ischemic heart disease accounts for almost 1.8 million annual deaths ${ }^{[1]}$. Nowadays, heart transplantation represents the only successful therapeutic approach for end-stage heart failure (HF) patients. Unfortunately, organ availability and immunological issues heavily hinder this strategy. The need to establish effective therapies, to improve survival and quality of life of the patients, 
has led researchers to investigate and develop alternative therapies able to protect, regenerate and functionally restore the damaged myocardium. The mammalian heart has been considered, for a long time, as a terminally differentiated organ incapable of regenerating after injury. In recent years, many evidences demonstrated that cardiomyocytes, during aging and after injury, are able to reentry in the cell cycle and promote cell renewal ${ }^{[2,3]}$. In addition, it has been identified the presence of several resident cardiac progenitor cells (CPCs) population that, after myocardial infarction (MI), are able to proliferate and differentiate into the cardiac lineages ${ }^{[4]}$. Unfortunately, inflammatory processes following cardiac injury, in addition to the unsuitable ischemic microenvironment and the lack of oxygen, are able to affect this endogenous regenerative process exacerbating tissue damages and promoting adverse remodeling. Accordingly, cardiac cell therapy (CCT) approach, based on isolation, expansion and injection of CPCs, might be a valid alternative to promote and support heart regeneration ${ }^{[5,6]}$. However, despite the encouraging preclinical and clinical results, these treatments have shown very limited improvement in the long term ${ }^{[7-9]}$. In fact, it has been demonstrated that many injected cells are lost within few hours after injection and only the $5-10 \%$ can be detected after one day in the damaged myocardium ${ }^{[10,11]}$. The limited engraftment and the subsequent reduced proliferation and differentiation potential of the transplanted cells, due to the interaction between injected CPCs, extracellular matrix (ECM) components and the local tissue condition, represent another important issue for the therapeutic outcome ${ }^{[10,11]}$. Therefore, the synergy between CCT and tissueengineering approaches, able to increase the engraftment and regenerative potential of injected cells, in addition to their anti-remodeling capacities and the possibility to stimulate resident cells, could represent a beneficial and valid alternative ${ }^{[12]}$. In the present review, we discuss the therapeutic role of CPC population and provide an overview on the state of the art and recent advantages on scaffoldbased therapy for infarcted myocardium in order to understand which step will be the next to be taken to improve cardiac regenerative medicine.

\section{CARDIAC ECM}

ECM is a key functional tissue structure, including growth factors, fibrous proteins and glycosaminoglycans (GAGs) produced and secreted by resident cells, able to create an in vivo specialized microenvironment in which cells survival and biological activity is preserved ${ }^{[13]}$. In the heart, ECM provides structural and functional integrity, mediating the mechanical connection among cardiomyocytes, cardiac fibroblasts (CFs) and blood vessels, able to guide organ development and physiologic repair and to affect cardiac functions ${ }^{[14-16]}$. CFs, that together with endothelial cells represent the higher portion of resident non-myocyte cells, are able to produce ECM and, at the same time, maintain its homeostasis, through the production of matrix metalloproteinases (MMPs), a group of ECM-degrading enzymes able to break down all the protein components of the matrix, and the tissue inhibitors of metalloproteinases (TIMPs) ${ }^{[17,18]}$. Several pre-clinical and clinical studies have underlined that an imbalance in ECM remodelling, which means an alteration between the MMPs and TIMPs production and function, is detrimental in the failing heart ${ }^{[19-23]}$. In fact, this maladaptive remodelling, bringing to an altered arrangement and reduced cross-linking between collagen fibres, contributes to reduce systolic performance, decreased compliance and diastolic dysfunction in failing human heart ${ }^{[24]}$. Furthermore, inflammatory cytokines such as interleukin-1b (IL1b), interleukin-6 (IL6) and tumor necrosis factor- $\alpha$ (TNF $\alpha$ ) can promote the differentiation of CFs into collagen-producing myofibroblasts, increasing the relative amount of the stiffer collagen type I over the more compliant collagen type III $^{[25-27]}$. The increase in myocardial stiffness, from a physiologic $10-20 \mathrm{kPa}$ Young's Modulus to a 50-200 $\mathrm{kPa}$ range, leads to an autocrine feedback signalling able to support a mechanically induced fibrosis that ends up in chronic scarring process ${ }^{[28]}$. Furthermore, it has been demonstrated that during this cardiac adverse remodeling, variations in ECM composition and its mechanical features can interfere with the cardiogenic potential of resident or transplanted $\mathrm{CPCs}^{[29]}$. In this optic, ECM and ECM-like materials represent functional and biocompatible tools with a great potential to serve as natural or nature-mimicking scaffolds in the field of regenerative medicine ${ }^{[30,31]}$.

\section{CPCS AND HEART REGENERATION}

The heart has been considered for a long time as a terminally differentiated organ with no intrinsic capacity to regenerate after myocardial injury. This concept is now being challenged and several evidences demonstrated that into the adult mammalian heart, both in normal and pathological conditions, myocytes are able to undergo mitosis and cytokinesis ${ }^{[32]}$. Furthermore, different resident cardiac progenitor cells (CPCs) populations have been identified both in the embryonic and adult heart and their potential use for cardiac regeneration has been deeply investigated for years ${ }^{[33]}$. 


\subsection{Embryonic CPCs}

During the embryonic development, multipotent cardiovascular progenitors (MCPs), which derive from the mesodermal lineage, contribute to the heart formation in two ways ${ }^{[34]}$. On one side, the First Heart Field (FHF), which is the classical cardiac crescent consisting of T-Box 5 (TBX5) positive cells, is known to contribute to the formation of the left ventricle and, partially, of the atria. From the other side, the Second Heart Field (SHF), mainly composed of LIMhomeobox Transcription Factor Islet-1 (ISL1) positive cells, contributes to the formation of the right ventricle, the outflow tract and the remaining parts of the atria ${ }^{[35,36]}$. Due to their ability to differentiate into cardiac and smooth muscle and vascular endothelium, MCPs represent a promising regenerative tool for heart repair ${ }^{[37,38]}$. In fact, embryonic stem cells (ESCs) have been deeply studied not only to investigate cardiac development and the function of human and murine heart cells, but also to determine the basic strategies of regenerative cell therapy ${ }^{[39-41]}$. Furthermore, several in vitro protocols have been developed to stimulate human ESCs differentiation in cardiomyocytes, providing a morphology and an expression profile similar to that of adult cardiomyocytes ${ }^{[42]}$. Briefly, cardiomyocytes markers are categorized in two principal groups: early and late differentiation. After 5-6 days of differentiation, GATA Binding Protein 4 (GATA-4), Isl1, and Kinase Insert Domain Receptor (KDR) become highly expressed. Later, between 8 and 10 days of differentiation, the expression levels of NK2 homeobox5 (NKX2.5), Tbx5, MyocytesSpecific Enhancer Factor 2C (MEF2C) and HAND1/2 reach an expression peak together with an increase in myofilament-related gene expressions, such as Troponin T2 (Tnnt2) and Myosin Heavy Chain 6 (Myh6) ${ }^{[43]}$. Nevertheless, despite MCPs high plasticity, their introduction into the clinical trial/therapeutic scenario is affected by several problems, in particular ethical issues, the genetic variability, the risk of immune rejection and the tumorigenic possibility ${ }^{[44]}$.

\subsection{Adult CPCs}

Even if their physiologic role in homeostasis and activation after injury still remains unclear, CPCs can be isolated from adult human and mammalian hearts with different approaches ${ }^{[45-47]}$. For example, side population cells (SP) are defined by their ability to efflux the DNA-binding dye Hoechst 33342 , whereas Sca $1^{+}$population is characterized by the expression of the stem cell antigen- ${ }^{[48,49]}$. Interestingly, in 2004 it has been demonstrated for the first time that human CPCs can be isolated, starting from explant cultures of percutaneous endomyocardial biopsy specimens, through their capacity to form spontaneously 3D spherical clusters, called cardiospheres (CSps) ${ }^{[50-53]}$.
CSps represent a perfect niche microenvironment in which it is possible to recognize, according to their expression pattern, two distinct compartments. The core, in which cells are characterized by a high proliferation rate, presents a cardiac progenitor immunophenotype dominated by the expression of stem cell and cardiomyocyte-related antigens, such as C-KIT, GATA-4, NKX2.5, CX43 and OCT4. On the contrary, peripheral cells are characterized by a more committed expression profile into endothelial, mesenchymal, or cardiomyogenic lineages (CD105, MHC, TNI, CD31, CD133, MDR1) ${ }^{[52,54]}$. CSps can be expanded in monolayer as CSps derived cells (CDCs) to obtain a culture enriched in CPCs, previously selected through the CSps formation step ${ }^{[51]}$. CDCs are defined by clonal growth capacity and, phenotypically, by several characteristic markers, such as a-SMA, CX43 and CD105 that positively identify more than $80 \%$ of CDCs, resulting negative, at the same time, for hematopoietic and endothelial progenitor cell markers ${ }^{[55]}$. Interestingly, CDCs can acquire a mature cardiomyocyte phenotype when co-cultured with neonatal rat ventricular myocytes (NRVMs) ${ }^{[55]}$. Although it has been analysed the therapeutic potential of other non-cardiac stem cell sources, such as embryonic cells, bone marrow-derived mesenchymal stem cells, endothelial progenitor cells, myoblasts and induced pluripotent stem cells, many evidences underlined that resident CPCs, especially CDCs, represent the better candidate for cardiac regenerative medicine ${ }^{[5,56-59]}$. In 2012, Li et al., using a mouse model of myocardial infarction (MI), demonstrated that the functional outcome of CDCs transplantation was superior to the transplantation of bone marrow mesenchymal stromal cells and adipose-derived regenerative cells ${ }^{[58]}$. Subsequently, other preclinical studies confirmed that CDCs therapy has multiple beneficial effects on the damaged myocardium, such as enhancement of cell survival, increase of blood supply and viable mass, reduction of inflammation and scar size and, in acute MI pig models, prevention of ischemic injury after reperfusion ${ }^{[60-65]}$. These encouraging preclinical results have paved the way to CDCs-based clinical trials. In 2012, the CADUCEUS study (NCT00893360) investigated the intracoronary administration of autologous CDCs after acute myocardial infarction ${ }^{[6]}$. In the 6-month follow-up, the safety of the cells was demonstrated in association with a reduction of the infarct scar size and an increase in myocardial viability and contractility ${ }^{[66]}$. Furthermore, after 1 year from the treatment, even if ventricular volumes and left ventricular ejection fraction (LVEF) did not increase, myocardial regeneration has been achieved, strengthened the therapeutic potential of $\mathrm{CDCs}^{\left[{ }^{[67]} \text {. }\right.}$ In the same year, another clinical trial started, the ALLSTAR study (NCT01458405), in order to evaluate 
the effect of allogeneic CDCs on scar size in patients with post-MI ischemic left ventricular dysfunction ${ }^{[68]}$. Unfortunately, the study is still in progress and results are not yet available. Interestingly, even if CPCs show a high differentiation potential in vitro, recent studies suggest that the in vivo direct differentiation following transplantation is not the primary mechanism by which these cells promote cardiac recovery ${ }^{[6]}$. In fact, a great proportion of CPCs therapeutic effects were shown to be attributable to indirect mechanisms of action able to exert protective and beneficial effects on the endogenous tissue. In a comparative study, it has been analysed the CPCs secretome profile, consisting of humoral factors, proteins, and molecules, underlining a highly complex and biological activity able to provide significant paracrine benefits than other progenitor populations, such as the bone marrow or adipose tissue ${ }^{[58]}$. Indeed, CPCs secretome exerts significant anti-apoptotic effects, promotes the recruitment of endogenous progenitors and the activation of endogenous cardioblasts ${ }^{[69-71]}$. In this context, also CPCs-derived exosomes are able to exert, once released in the extracellular microenvironment, positive therapeutic effects through multiple mechanisms interacting with different target cells, such as endothelial cells and cardiomyocytes ${ }^{[72-74]}$. Overall, despite all these encouraging results many critical issues, including the challenges of electrical coupling, undetermined mechanism aspects and, above all, the long term engraftment and survival of injected cells, should be addressed before CPCs could be considered as a strong therapeutic tool for regenerative medicine applications ${ }^{[75]}$.

\section{TISSUE ENGINEERING FOR CARDIAC REGENERATION}

Tissue engineering could be defined as a synergistic cooperation, between biotechnological, biomedical and engineering knowledges and applications, which aims to regenerate damaged tissues and/or organs. In the cardiac regenerative medicine field, one of the most important issues of tissue engineering is the development of functional artificial tissues and organs. The ideal engineered product has to provide an adequate cellular niche microenvironment able to mechanically support and direct cell growth, differentiation and engraftment, protect the transplanted cells from the hostile infarcted tissue environment and, as an outcome, to promote tissue remodeling/regeneration ${ }^{[12,76]}$. For all those reasons, biocompatibility, biodegradability and permeability represent the unavoidable characteristics that the biomaterial must possess ${ }^{[77]}$.

\subsection{Polymers for cardiac tissue engineering}

Polymers, characterized by a wide range of compositions and, thus, properties, represent one of the most used classes of biomaterials to recreate EMC-mimicking scaffolds for cardiac regeneration. In general, polymers can be classified in synthetic or natural (Table 1). Briefly, synthetic materials, such as Polyglycolic acid (PGA), polylactic-Iacid (PLLA), polylactic glycolic acid (PLGA) and polyurethane (PU), that are extremely malleable, are not always biodegradable and often prevent vascular and parenchymal cell attachment and infiltration ${ }^{[78,79]}$. Besides, natural polymers, or biopolymers, such as collagen, elastin, chitosan, cellulose and hyaluronic acid, even if exhibit a higher degree of biocompatibility and promote cell migration and differentiation, present a low mechanical strength for cardiovascular application ${ }^{[80]}$. Therefore, it has been proposed the combination of synthetic and natural biomaterials to improve the weakness of each polymer to create a scaffold with better properties ${ }^{[79,81]}$. Nowadays, one of the most promising approaches investigated for cardiac tissue engineering involves the use of bioactive glasses (BGs) ${ }^{[22]}$. BGs, since their discovery by Hench et al in 1969, have gained much attention in tissue engineering due to their highly biocompatibility and bioactivity and are recognized as the second generation of biomaterials with the ability to bond to the living tissues ${ }^{[83]}$. Based on their composition, BGs can be categorized as silicate-based glasses, borosilicate and borate-based glasses, and phosphate-based glasses. Recently, BGs has been considered as suitable materials for cardiac tissue engineering, especially in the form of nanoparticles in combination with biocompatible polymers acting as soft matrices ${ }^{[82,84]}$.

Table 1. Differences between synthetic and natural polymers commonly used in cardiac tissue engineering.

\begin{tabular}{llll}
\hline & Biodegradability & Malleability & Bioactivity \\
\hline Synthetic polymers & Low & High & Yes \\
Natural polymers & High & Low & Yes \\
Combination of synthetic and natural polymers & High & High & Yes \\
\hline
\end{tabular}




\subsection{Native decellularized ECM as a biomaterial}

In the last years, many studies investigated the creation of autologous biological scaffolds composed of native ECM, derived from the decellularization of tissues or organs, in order to provide tissue-specific ECM compositions, which can influence the behavior of resident and/or transplanted cells ${ }^{[85,86]}$. Recently, Seo et al. developed a detergent-free decellularization protocol based on supercritical carbon dioxide and ethanol co-solvent (scCO2-EtOH) method able to prevent ECM structure disruption. They tested this decellularized ECM (dECM) on rat heart tissues, demonstrating that heart-derived dECM with scCO2$\mathrm{EtOH}$ treatment, compared to a collagen control group, represented a promising angiogenic material for healing in ischemic disease ${ }^{[87]}$. In general, the decellularization process, removing cell components, is able to leave unchanged tissue architecture, ECM components and, thus, mechanical properties ${ }^{[88,89]}$. In addition, eliminating antigenicity, in case of xenogenic or allogeneic transplant it reduces the possibility of inflammatory and immune responses ${ }^{[90-94]}$. A variety of non-cardiac tissue types have been tested as decellularized ECM source in order to repair myocardium after an ischemic injury, such as small intestine submucosa or urinary bladder matrix ${ }^{[95-97]}$. However, it has been demonstrated that cardiac ECM exhibits tissue-specific composition and organization, therefore the utilization of an ECM from non-cardiac tissues may fail to provide proper stimulations to cells in the myocardium ${ }^{[98,99]}$. Nowadays, pericardial and myocardial tissues represent the principal cardiacsource for $\mathrm{ECM}^{[100,101]}$. The pericardium is a doublewalled fibrous sac, primarily composed of collagen and elastin, that contains the heart and the roots of the great vessels, fixing them to the mediastinum, and it is able to confer protection against infections and lubricates the heart ${ }^{[5,102]}$. Myocardium is the thick contractile middle layer of the heart wall composed of muscle cells. Myocardial ECM is principally composed of a mixture of different collagen types (80\% type I, $10 \%$ type III, < 5\% type V) in addition to a small amount of laminin, elastin and fibronectin ${ }^{[103]}$.

\subsection{D scaffolds}

Despite contributions in biomedical research and the development of more complex 2D culture platforms, it is difficult to predict, recapitulate and understand cell-cell interactions and functions, naturally designed for a 3D environment, in a bi-dimensional context. Cardiac ECM, secreted by resident cells, consists of structural and functional three-dimensional molecules-based organization that establish cardiac ultrastructure and microenvironment ${ }^{[104]}$. In this optic, 3D scaffolds, could represent a perfect physiological and pliable pattern to promote an effective tissue remodelling and regeneration in damaged cardiac tissues, enhancing in resident and/or transplanted CPCs chemotaxis, proliferation and differentiation ${ }^{[105]}$. In terms of patch architecture many different systems have been investigated and are available for scaffold creation. In 2002, Taylor et al. demonstrated that 3D biodegradable collagen sponge-based scaffold, composed of interconnected micropores, with notable fluid absorption and hydrophilicity, was able to maintain viable human cardiac valve interstitial cells (ICs) and to enhance the capacity of those cells to express their original phenotype, making this scaffold suitable to resemble a valve leaflet ${ }^{[106]}$. A different approach is based on mesh-based scaffold, in which biomaterial fibers are braided in a 3D structure with uniform porosity and dimensions similar to the ones naturally occurring in the ECM. A comparison of the structural and biological features of a collagen fibrous ball-of-thread-like versus a gelatin trabecular sponge-like bio-constructs, seeded with human CSps, demonstrated that both scaffolds, despite their structure or composition, recreate a more pro-survival and cardiac-specific differentiative microenvironment than the normal in vitro culture protocols $^{[107]}$. Recently, it has been compared, both in vitro and in vivo, the effect of a biodegradable and non-toxic PU-based scaffold, grafted with laminin-1 (PU-LN1) or gelatin (PU-G), populated with human $\mathrm{CPCs}^{[108]}$. Compared to the PU-G, used as control, PU-LN1 is able to highly promote cells proliferation, protection from apoptosis and expression of differentiation markers for cardiomyocytes, endothelial and smooth muscle cells. Furthermore, once LN1 scaffolds are implanted subcutaneously in a mouse model of MI, they are able to minimize inflammation and, stimulating blood vessel density around them, to perfectly integrate with the host tissue ${ }^{[108]}$. Similarly, Wang et al. developed, for the first time, a 3D collagen-elastin scaffold, for heart valve engineering, without chemical crosslinker and assembled by temperature-triggered gelling ${ }^{[109]}$. Whoever the reduced cell toxicity, the novelty of this approach consists in the co-culture of valvular interstitial cells (VICs), encapsulated in the matrix, with valvular endothelial cells (VECs), cultured on the surface of the 3D structure. Thereby, this scaffold was able to stimulate cell proliferation, to increase actin filaments and to improve integrin $\beta 1$ expression, representing a novel platform to better study and understand, cell-cell or cell-matrix interactions and, possibly, to improve cardiac valve tissue engineering ${ }^{[109]}$. As said previously, native ECM could represent a suitable mechanical and biological environment able to ensure cell engraftment and to improve therapeutic and regenerative properties of resident and transplanted cells ${ }^{[29,110,111]}$. Several studies demonstrated the positive effects of cardiac dECM patch in damaged cardiac tissue. In 2016, 
a porcine cardiac dECM was implanted in acute and 8-weeks chronic MI rat models ${ }^{[112]}$. In both conditions, dECM was rapidly vascularized and was able to promote an improvement in cardiac function through the recruitment of resident CPCs, their stimulation towards the cardiomyocyte lineage and their arrangement in partially striated and immature muscle fibers ${ }^{[112]}$. Furthermore, in the last years, even if the debate on the benefits of this method is still in progress, it has been investigated the possibility to combine in vitro cardiac dECM with CPCs and to apply this "cellularized" patch for in vivo treatments ${ }^{[113-115]}$. In 2014, Rajabi-Zeleti et al. fabricated a 3D macroporous cardiac patch from human decellularized pericardium membranes (dPM) ${ }^{[116]}$. They demonstrated that the dPM macroporous scaffold is able to enhance the proliferation, viability, migration and differentiation of CPCs in vitro. Furthermore, after an in vivo subcutaneous implantation, besides the improvement in cells differentiation, the dPM scaffold was able to stimulate angiogenesis and to avoid immune rejection ${ }^{[116]}$. Recently, a 3D macroporous cardiac patch from solubilized myocardium dECM with the addition of chitosan (CS) has been successfully designed and fabricated ${ }^{[110]}$. The novelty was represented by the possibility, modifying the percentage of solubilized $\mathrm{dECM}$ and $\mathrm{CS}$, to modulate the stiffness of the scaffold according to the requirements. CPCs seeded on this malleable microporous myocardium scaffold present a high proliferation rate and viability in addition to a significant increase in expression of early cardiac markers ${ }^{[110]}$. Taking together, all these results could be give reasons to investigate and to elucidate how fabricated scaffold could be used to stimulate CPCs differentiation into cardiomyocytes, aiming to create the perfect dECM-derived cardiac regenerative patch.

\subsection{Hydrogels}

One of the principal aim of cardiac regeneration is to repair ischemic tissues, stimulating the formation of new blood vessels, through the delivery of angiogenic growth factors, stem cells or expansion of pre-existing cells. Despite the encouraging results previously analyzed, one of the problem associated with the use of $3 D$ patch for cardiac repair is the lack of a complete vascularization able to affect the thickness of the scaffold and, as a consequence, cells viability ${ }^{[117]}$. Furthermore, the necessity to develop minimally invasive techniques requires the setting up of alternatives. In this optic, injectable hydrogels represent the most investigated biomaterials forms for both in vitro and in vivo cardiac tissue engineering (Table 2) ${ }^{[118,119]}$. Hydrogels can be defined as viscoelastic system, composed of a natural or synthetic extensive water-swollen polymeric network, that can be injected in liquid state and then able to form a solid gel in situ ${ }^{[120]}$. In 2004, Christman et al. investigated, for the first time, the effects of an injectable biopolymeric fibrin scaffold to deliver cells directly into the infarct wall of Ml model rats ${ }^{[121]}$. Their rationale was that the direct injection in the infarcted myocardium of cells, in this case skeletal myoblasts, would increase cell transplant retention and survival within the infarct. Even if fibrin glue was not able to increase cells retention, the injection of this hydrogel was able to promote cells survival and blood supply to the ischemic myocardium leading to a reduction of infarct size and myocardial remodeling ${ }^{[121]}$. In addition, the same group demonstrated that an injectable porcine ventricular ECM-derived hydrogel was able to promote in vitro proliferation, survival and cardiogenic potential of embedded human Sca $1^{+}$CPCs population ${ }^{[122]}$. The subsequent injection of the hydrogel in an induced $\mathrm{MI}$ rat model resulted in a reduced cardiomyocyte apoptosis, cardiac hypertrophy and fibrosis. On the other side, the resulted increase in resident CPCs recruitment, in cardiac transcription factor expressions and in the neovascularization of the infarcted tissue, has led to an improvement in global cardiac functions and hemodynamics ${ }^{[123-125]}$. These results in accordance with the needed to provide increasingly effective therapeutic tools have triggered a still ongoing clinical trial (NCT02305602) that evaluates the safety and feasibility of the porcine myocardial dECM-derived hydrogel delivered, in a minimally-invasive procedure, via catheter to the damaged cardiac tissue in patients after myocardial infarction ${ }^{[125-127]}$. It has been deeply demonstrated that human cardiac dECM-derived hydrogels support in vitro proliferation and differentiation of pluripotent stem cells along the cardiomyocyte lineage in addition to a cytoprotective effect ${ }^{[28,129]}$. Nonetheless, the porcine dECM application is favoured than human one because of the rarity of collecting healthy human hearts, the significant patient-to-patient variability and, most of all, the aging-related alteration in ECM composition $^{[27,130,131]}$. Either way, other clinical trials have been developed to investigate the in vivo therapeutic efficacy, safety and feasibility of other hydrogel compositions ${ }^{[126,132]}$. For example, the PRESERVATION-1 trial (NCT01226563) evaluated the safety and effectiveness of an alginate hydrogel, intracoronary injected, for the prevention of ventricular remodeling and congestive heart failure after $\mathrm{MI}^{[133,134]}$. Furthermore, despite the hydrogel composition, the suitable injection site represents another issue to be investigated. In a recent study by Garcia et al., it has been tested on a pig model of atrial fibrillation (AF) the efficacy of amiodarone, an effective lipophilic medication approved for rhythm control but with a significant systemic toxicity, encapsulated in a PEG-based hydrogel (50 mg amiodarone/5 mL gel) and injected directly on the atrial pericardium. 
They demonstrated that pericardium hydrogels can deliver therapeutics directly to the heart enabling a continued release of drug for several weeks and reducing off-target organ accumulations ${ }^{[135]}$. These results highlight the possibility to use pericardium as an alternative therapeutic site for treatment strategy for AF and other cardiovascular diseases. Interestingly, Zhang et al., aimed to test in vitro the efficacy of the pretreatment with pericardial fluid (PF) from rats with myocardial infarction (PFMI) on CSps and to assess, for the first time, the therapeutic in vivo effect on rat models of $\mathrm{Ml}$ by administering these pretreated CSps, embedded in a commercial hydrogel, in the pericardial cavity ${ }^{[136]}$. In vitro experiments demonstrated that PFMI pretreatment enhanced CSps survival and their commitment in cardiac muscle cells. Interestingly, the in vivo pericardial application of hydrogel with functionally enhanced CSps demonstrated that these cells could differentiate in cardiac myocytes and, in a paracrine way, to improve cardiac function and myocytes survival, to stimulate angiogenesis into the infarcted myocardium and to reduce myocardial fibrosis ${ }^{[136]}$.

Table 2. Principal advantages and disvantages of 3D Scaffold vs. Hydrogel.

\begin{tabular}{|c|c|c|}
\hline & Advantages & Disvantages \\
\hline 3D scaffold & $\begin{array}{l}\text { - Three-dimensional molecules-based organization } \\
\text { similar to natural ECM } \\
\text { - Biodegradability } \\
\text { - Malleability } \\
\text { - Bioactivity }\end{array}$ & $\begin{array}{l}\text { - Lack of a complete vascularization } \\
\text { - Invasiveness surgical procedure }\end{array}$ \\
\hline Hydrogel & $\begin{array}{l}\text { - Minimally invasive techniques requires } \\
\text { - Bioactivity } \\
\text { - Biodegradability }\end{array}$ & $\begin{array}{l}\text { - Less mechanical strength } \\
\text { - Pathogen risk potential }\end{array}$ \\
\hline
\end{tabular}

\subsection{Bioprinting}

Bioprinting technique, earlier called cytoscribing, represents the last frontier in cardiac tissue engineering and could be defined as computeraided additive biofabrication of 3D cellular tissue constructs $^{[137-139]}$. This quickly progressing automated technology allows to strictly controlling the micro and macro-architecture of replacement tissues and organs providing high reproducibility and precise control $^{[140]}$. Up to date, many tissue types, such as bone, vasculature, neural tissue and cardiac muscle, have been created starting from autologous and patient specific primary or stem cells ${ }^{[141-143]}$. The basic unit of the entire printing process is the socalled "bioink" that has to be biocompatible and stable from a mechanical and structural point of view ${ }^{[144,145]}$. Generally, the printable material is composed by living cells, such as embryonic, adult, or induced pluripotent stem cells, proteins and other active biological molecules loaded into a matrix, mimicking the ECM. According to their base materials, bioinks could be divided in two principal groups: scaffoldbased and scaffold-free bioinks (Table 3) ${ }^{[139,146-148]}$. In the first group, cells are seeded within natural or synthetic hydrogels, such as collagen, fibrin and polyethylene glycol, or in $\mathrm{dECM}^{[146,149]}$. On the other side, cells in the scaffold-free bioinks are printed without matrix support and the ability to deposit their own ECM is exploited to confer support for cell-cell communication and proliferation to create strands or spheroids ${ }^{[147,148]}$. Despite the selected bioink, up-to-date three different bioprinting processes are available ${ }^{[150]}$. The technical gold standards are represented by viability, spreading and proliferation of cells, in addition to the functionality of the bioprinted constructs $^{[151]}$. Droplet-based bioprinting (DBB), based on a two-dimensional inkjet printing, was the first developed and it is still the most commonly used methodology. Even if DBB is cost-effective and allows obtaining an $85 \%$ of bioink-cell viability, the lower resolution, due to the wide-range of drop size (50-300 $\mu \mathrm{m})$, represents an important technical limitation ${ }^{[152,153]}$. In the Extrusion-based bioprinting (EBB), bioink is deposited in cylindrical lines, instead of droplets, by a controlled fluidic dispensing system. EBB offers a great flexibility in printing a wide range of bioinks, such as spheroids or tissue strands, with a considerable print speed, encouraging scalability and clinical translation. However, from a practical point of view, the resolution of printed features is still very low and the percentage of cell viability is around the $80 \%{ }^{[153,154]}$. Finally, in the Laser-based bioprinting (LBB), also known as Stereolithography- 
based bioprinting (SBB), a laser pulse induces the bioink to acquire a drop shape in order to form 3D constructs. Throughout this artifice, it is possible to obtain a higher precision and resolution, mechanical stress is reduced and cell viability stands around the $95 \%{ }^{[153]}$. Unfortunately, at least for the moment, the high costs and the complexity of the laser system make this technology not easily accessible. From a practical point of view, currently bioprinting research for cardiovascular tissue regeneration largely focuses on the myocardium, heart valves, and vasculature ${ }^{[150]}$. For example, Gaetani et al. evaluated the therapeutic potential of a 3D-printed patch composed of human Sca $1^{+}$progenitor cells in a hyaluronic acid/gelatin (HA/gel) based matrix, transplanted in a mouse model of MI. They observed that the application of the patch led to a significant reduction in adverse remodeling and preservation of cardiac performance. Furthermore, the matrix supported the long-term in vivo survival and engraftment of CPCs, which exhibited a temporal increase in cardiac and vascular differentiation markers over the course of the 4 week follow-up period. Overall, they developed an effective and translational approach to enhance CPCs delivery and action in the heart ${ }^{[155]}$. Wang et al. have recently provided another example of the feasibility of bioprinting in achieving functional cardiac tissues ${ }^{[156]}$. They integrated isolated neonatal rat ventricular cardiomyocytes in a composite hydrogels preparation and dispensed this bio-mixture to form a string form or patch form. Interestingly, after 1 week in culture, they observed a spontaneous and synchronous beating of bioprinted cardiac tissues and, in parallel, the formation of dense and uniformly aligned heart muscle bundles. Differently, Ong et al. proposed a culture protocol for 3D bioprinting of cardiac tissue without the use of biomaterials ${ }^{[157]}$. Firstly, they co-cultured isolated cardiomyocytes, endothelial cells and fibroblasts in low attachment 96-well plates leading to the formation of spontaneous beating spheroids. The possibility to create different mixtures, which differ in term of cell type's percentage, allows obtaining, depending on the purpose, many different types of printed cardiac patches, with distinctive histological and mechanical properties. Furthermore, the innovative feature of this protocol was the possibility to pick up individual spheroids using vacuum suction and position them on a needle array. Accordingly, spheroids could be precisely positioned in any desired configuration and fused together to create a scaffold-free functional 3D bioprinted patch with mechanical integration of component spheroids. As said previously, bioprinting has been explored also for cardiac valve construction in order to enhance physiological characteristics, such as durability or anticoagulation, compared to traditional mechanical and biological prosthesis valve replacements ${ }^{[158]}$. Therefore, many evidences, underlined how, through bioprinting approaches, it is possible to obtain a better ECM deposition, an upregulation of muscle actin and a strong human aortic valvular interstitial cells (HAVICs) phenotype ${ }^{[150,159,160]}$. To summarize, compared to traditional therapeutic strategies, 3D bioprinting may offer a unique approach for creating complicated cardiovascular implants with biomimetic features, which are capable of recapitulating both the native physiochemical and biomechanical characteristics of the cardiovascular system. Furthermore, the current implementation of this technique with the latest pre-vascularization technologies will lead to the improvement of blood perfusion throughout the engineered tissue. For this reason, in the near future, it will be implemented a physiological mimicry of human cardiovascular tissues in order to be applied for an effective drug development, therapeutic approaches and, through the reconstruction of fully functional organ, to overcome the shortage of organ transplantation ${ }^{[150,161,162]}$.

Table 3. Advantages and disvantages of Scaffold-based and Scaffold-free bioinks.

\begin{tabular}{|c|c|c|c|}
\hline & Materials & Advantages & Disvantages \\
\hline $\begin{array}{l}\text { Scaffold-based } \\
\text { bioinks }\end{array}$ & $\begin{array}{l}\text { Natural or synthetic } \\
\text { hydrogels or dECM }\end{array}$ & $\begin{array}{l}\text { - Easy bioprintability } \\
\text { - High resolution } \\
\text { - Economical }\end{array}$ & $\begin{array}{l}\text { - Toxicity } \\
\text { - Degradation } \\
\text { - Limited cell-cell interactions } \\
\text { - Medium tissue biomimicry }\end{array}$ \\
\hline $\begin{array}{l}\text { Scaffold-free } \\
\text { bioinks }\end{array}$ & $\begin{array}{l}\text { Cells are printed } \\
\text { without a matrix } \\
\text { support }\end{array}$ & $\begin{array}{l}\text { - Rapid tissue maturation } \\
\text { and generation } \\
\text { - High tissue biomimicry }\end{array}$ & $\begin{array}{l}\text { - Difficult bioprintability } \\
\text { - Need for high cell numbers } \\
\text { - High costs }\end{array}$ \\
\hline
\end{tabular}




\section{CONCLUSIONS}

Enormous progress has been made, in the last decades, in cardiac tissue engineering, rendering the clinical application of biomaterials increasingly plausible. However, the concepts discussed in the present review represent just a portion of the great amount of investigations that are still ongoing to insert cardiac tissue engineering in the clinical routine. Actually, the complexity of the heart system, not only because of its mechanical and structural function but also due to its electrical properties as well, still need many efforts to implement our knowledge of the entire panel of variables that influence its regeneration and repair mechanisms. For these reasons, it would be desirable, in the near future, to support scientific cooperation in order to build consensus in all the aspects underlined here, starting from the detection of the best material to the suitable scaffold production technique, without

\section{REFERENCES}

1. Ibanez B, James S, Agewall S, Antunes MJ, Bucciarelli-Ducci C, Bueno $\mathrm{H}$, Caforio ALP, Crea F, Goudevenos JA, Halvorsen S, Hindricks G, Kastrati A, Lenzen MJ, Prescott E, Roffi M, Valgimigli M, Varenhorst C, Vranckx P, Widimský P; ESC Scientific Document Group. 2017 ESC Guidelines for the management of acute myocardial infarction in patients presenting with ST-segment elevation: The Task Force for the management of acute myocardial infarction in patients presenting with ST-segment elevation of the European Society of Cardiology (ESC). Eur Heart J. 2018; 39(2): 119-177.

2. Uchida S, De Gaspari P, Kostin S, Jenniches K, Kilic A, Izumiya Y, Shiojima I, Grosse Kreymborg K, Renz H, Walsh K, Braun T. Sca1-derived cells are a source of myocardial renewal in the murine adult heart. Stem Cell Reports. 2013; 1(5): 397-410.

3. Ahuja P, Sdek P, MacLellan WR. Cardiac myocyte cell cycle control in development, disease, and regeneration. Physiol Rev. 2007; 87(2): 521-544.

4. Nurzynska D, Di Meglio F, Romano V, Miraglia R, Sacco AM, Latino F, Bancone C, Della Corte A, Maiello C, Amarelli C, Montagnani S, Castaldo C. Cardiac primitive cells become committed to a cardiac fate in adult human heart with chronic ischemic disease but fail to acquire mature phenotype: genetic and phenotypic study. Basic Res Cardiol. 2013; 108(1): 320. overlooking the selection of the powerful cellular therapeutic tool. In fact, only in this way many issues could be solved boosting cardiac tissue engineering as an effective therapeutic choice for millions of heart patients.

\section{CONFLICTS OF INTEREST}

The authors declare that there is no conflict of interest regarding the publication of this paper.

\section{AUTHOR CONTRIBUTIONS}

F.A. was in charge of overall direction and planning. F.A and V.P. devised the main conceptual ideas and proof outline. V.P., T.D.R. and F.A. wrote the manuscript.

5. Forte E, Chimenti I, Barile L, Gaetani R, Angelini F, lonta V, Messina E, Giacomello A. Cardiac cell therapy: the next (re)generation. Stem Cell Rev. 2011; 7(4): 1018-1030.

6. Pagano F, Picchio V, Angelini F, laccarino A, Peruzzi M, Cavarretta E, Biondi-Zoccai G, Sciarretta S, De Falco E, Chimenti I, Frati G. The Biological Mechanisms of Action of Cardiac Progenitor Cell Therapy. Curr Cardiol Rep. 2018; 20(10): 84.

7. Bruyneel AA, Sehgal A, Malandraki-Miller S, Carr C. Stem Cell Therapy for the Heart: Blind Alley or Magic Bullet? J Cardiovasc Transl Res. 2016; 9(5-6): 405-418.

8. Gaetani R, Barile L, Forte E, Chimenti I, Ionta V, Di Consiglio A, Miraldi F, Frati G, Messina E, Giacomello A. New perspectives to repair a broken heart. Cardiovasc Hematol Agents Med Chem. 2009; 7(2): 91-107.

9. Zwetsloot PP, Végh AM, Jansen of Lorkeers SJ, van Hout GP, Currie GL, Sena ES, Gremmels H, Buikema JW, Goumans MJ, Macleod MR, Doevendans PA, Chamuleau SA, Sluijter JP. Cardiac Stem Cell Treatment in Myocardial Infarction: A Systematic Review and MetaAnalysis of Preclinical Studies. Circ Res. 2016; 118(8): 1223-1232.

10. Terrovitis J, Lautamäki R, Bonios M, Fox J, Engles JM, Yu J, Leppo MK, Pomper MG, Wahl RL, Seidel J, Tsui BM, Bengel FM, Abraham MR, Marbán $E$. Noninvasive quantification and optimization of 
acute cell retention by in vivo positron emission tomography after intramyocardial cardiac-derived stem cell delivery. J Am Coll Cardiol. 2009; 54(17): 1619-1626.

11. Terrovitis JV, Smith RR, Marbán E. Assessment and optimization of cell engraftment after transplantation into the heart. Circ Res. 2010; 106(3): 479-494.

12. Gaetani R, Rizzitelli G, Chimenti I, Barile L, Forte E, lonta V, Angelini F, Sluijter JP, Barbetta A, Messina E, Frati G. Cardiospheres and tissue engineering for myocardial regeneration: potential for clinical application. J Cell Mol Med. 2010; 14(5): 1071-1077.

13. Yue B. Biology of the extracellular matrix: an overview. J Glaucoma. 2014; 23(8 Suppl 1): S20-S23.

14. Moore-Morris T, Guimarães-Camboa N, Yutzey KE, Pucéat M, Evans SM. Cardiac fibroblasts: from development to heart failure. J Mol Med (Berl). 2015; 93(8): 823-830.

15. Fan D, Takawale A, Lee J, Kassiri Z. Cardiac fibroblasts, fibrosis and extracellular matrix remodeling in heart disease. Fibrogenesis Tissue Repair. 2012; 5(1): 15.

16. de Haas HJ, Arbustini E, Fuster V, Kramer $\mathrm{CM}$, Narula J. Molecular imaging of the cardiac extracellular matrix. Circ Res. 2014; 114(5): 903-915.

17. Pinto AR, Ilinykh A, Ivey MJ, Kuwabara JT, D'Antoni ML, Debuque R, Chandran A, Wang L, Arora K, Rosenthal NA, Tallquist MD. Revisiting Cardiac Cellular Composition. Circ Res. 2016; 118(3): 400-409.

18. Turner NA, Porter KE. Regulation of myocardial matrix metalloproteinase expression and activity by cardiac fibroblasts. IUBMB Life. 2012; 64(2): 143-150.

19. Ryan TD, Rothstein EC, Aban I, Tallaj JA, Husain A, Lucchesi PA, Dell'Italia LJ. Left ventricular eccentric remodeling and matrix loss are mediated by bradykinin and precede cardiomyocyte elongation in rats with volume overload. J Am Coll Cardiol. 2007; 49(7): 811-821.

20. Spinale FG, Coker ML, Thomas CV, Walker JD, Mukherjee R, Hebbar L. Time-dependent changes in matrix metalloproteinase activity and expression during the progression of congestive heart failure: relation to ventricular and myocyte function. Circ Res. 1998; 82(4): 482-495.

21. Kim HE, Dalal SS, Young E, Legato MJ, Weisfeldt ML, D'Armiento J. Disruption of the myocardial extracellular matrix leads to cardiac dysfunction. J Clin Invest. 2000; 106(7): 857-866.
22. Ahmed SH, Clark LL, Pennington WR, Webb CS, Bonnema DD, Leonardi $\mathrm{AH}$, et al. Matrix metalloproteinases/tissue inhibitors of metalloproteinases: relationship between changes in proteolytic determinants of matrix composition and structural, functional, and clinical manifestations of hypertensive heart disease. Circulation. 2006; 113(17): 2089-2096.

23. Li L, Zhao Q, Kong W. Extracellular matrix remodeling and cardiac fibrosis. Matrix Biol. 2018; 68-69: 490-506.

24. Brilla CG, Rupp H. Myocardial collagen matrix remodeling and congestive heart failure. Cardiologia. 1994; 39(12 Suppl 1): 389-393.

25. Westermann D, Lindner D, Kasner M, Zietsch C, Savvatis K, Escher F, von Schlippenbach J, Skurk C, Steendijk P, Riad A, Poller W, Schultheiss HP, Tschöpe C. Cardiac inflammation contributes to changes in the extracellular matrix in patients with heart failure and normal ejection fraction. Circ Heart Fail. 2011; 4(1): 44-52.

26. Berk BC, Fujiwara K, Lehoux S. ECM remodeling in hypertensive heart disease. J Clin Invest. 2007; 117(3): 568-575.

27. Frangogiannis NG. The extracellular matrix in myocardial injury, repair, and remodeling. J Clin Invest. 2017; 127(5): 1600-1612.

28. Pesce M, Messina E, Chimenti I, Beltrami AP. Cardiac Mechanoperception: A Life-Long Story from Early Beats to Aging and Failure. Stem Cells Dev. 2017; 26(2): 77-90.

29. Pagano F, Angelini F, Castaldo C, Picchio V, Messina E, Sciarretta S, Maiello C, BiondiZoccai G, Frati G, Meglio FD, Nurzynska $D$, Chimenti I. Normal versus Pathological Cardiac Fibroblast-Derived Extracellular Matrix Differentially Modulates Cardiosphere-Derived Cell Paracrine Properties and Commitment. Stem Cells Int. 2017; 2017: 7396462.

30. Hinderer S, Layland SL, Schenke-Layland K. ECM and ECM-like materials - Biomaterials for applications in regenerative medicine and cancer therapy. Adv Drug Deliv Rev. 2016; 97 : 260-269.

31. Hematti P. Role of Extracellular Matrix in Cardiac Cellular Therapies. Adv Exp Med Biol. 2018; 1098: 173-188.

32. Beltrami AP, Urbanek K, Kajstura J, Yan SM, Finato $\mathrm{N}$, Bussani $\mathrm{R}$, et al. Evidence that human cardiac myocytes divide after myocardial infarction. $\mathrm{N}$ Engl J Med. 2001; 344(23): 1750-1777. 
33. Smith RR, Barile L, Messina E, Marbán E. Stem cells in the heart: what's the buzz all about? Part 2: Arrhythmic risks and clinical studies. Heart Rhythm. 2008; 5(6): 880-887.

34. Sedmera D, McQuinn T. Embryogenesis of the heart muscle. Heart Fail Clin. 2008; 4(3): 235-245.

35. Pandur P, Sirbu IO, Kühl SJ, Philipp M, Kühl M. Islet1-expressing cardiac progenitor cells: a comparison across species. Dev Genes Evol. 2013; 223(1-2): 117-129.

36. Moretti A, Caron L, Nakano A, Lam JT, Bernshausen A, Chen Y, Qyang Y, Bu L, Sasaki M, Martin-Puig S, Sun Y, Evans SM, Laugwitz $\mathrm{KL}$, Chien KR. Multipotent embryonic isl1+ progenitor cells lead to cardiac, smooth muscle, and endothelial cell diversification. Cell. 2006; 127(6): 1151-1165.

37. Christoforou N, Oskouei BN, Esteso P, Hill CM, Zimmet JM, Bian W, Bursac N, Leong KW, Hare JM, Gearhart JD. Implantation of mouse embryonic stem cell-derived cardiac progenitor cells preserves function of infarcted murine hearts. PLoS One. 2010; 5(7): e11536.

38. Christoforou N, Miller RA, Hill CM, Jie CC, McCallion AS, Gearhart JD. Mouse ES cellderived cardiac precursor cells are multipotent and facilitate identification of novel cardiac genes. J Clin Invest. 2008; 118(3): 894-903.

39. Evans T. Embryonic Stem Cells as a Model for Cardiac Development and Disease. Drug Discov Today Dis Models. 2008; 5(3): 147-155.

40. Van Vliet P, Wu SM, Zaffran S, Pucéat M. Early cardiac development: a view from stem cells to embryos. Cardiovasc Res. 2012; 96(3): 352-362.

41. Menasché $P$, Vanneaux V, Fabreguettes JR, Bel A, Tosca L, Garcia S, Bellamy V, Farouz Y, Pouly $J$, Damour O, Périer MC, Desnos $M$, Hagège A, Agbulut O, Bruneval P, Tachdjian G, Trouvin $\mathrm{JH}$, Larghero J. Towards a clinical use of human embryonic stem cell-derived cardiac progenitors: a translational experience. Eur Heart J. 2015; 36(12): 743-750.

42. Boheler KR, Czyz J, Tweedie D, Yang HT, Anisimov SV, Wobus AM. Differentiation of pluripotent embryonic stem cells into cardiomyocytes. Circ Res. 2002; 91(3): 189-201.

43. Rajala K, Pekkanen-Mattila M, Aalto-Setälä K. Cardiac differentiation of pluripotent stem cells. Stem Cells Int. 2011; 2011: 383709.

44. Anderson ME, Goldhaber J, Houser SR, Puceat M, Sussman MA. Embryonic stem cell-derived cardiac myocytes are not ready for human trials. Circ Res. 2014; 115(3): 335-338.
45. Chimenti I, Forte E, Angelini F, Giacomello A, Messina $\mathrm{E}$. From ontogenesis to regeneration: learning how to instruct adult cardiac progenitor cells. Prog Mol Biol Transl Sci. 2012; 111: 109-137.

46. Le T, Chong J. Cardiac progenitor cells for heart repair. Cell Death Discov. 2016; 2: 16052.

47. Barile L, Chimenti I, Gaetani R, Forte E, Miraldi F, Frati G, Messina E, Giacomello A. Cardiac stem cells: isolation, expansion and experimental use for myocardial regeneration. Nat Clin Pract Cardiovasc Med. 2007; 4 Suppl 1: S9-S14.

48. van Vliet $P$, Sluijter JP, Doevendans PA, Goumans MJ. Isolation and expansion of resident cardiac progenitor cells. Expert Rev Cardiovasc Ther. 2007; 5(1): 33-43.

49. Barile L, Messina E, Giacomello A, Marbán E. Endogenous cardiac stem cells. Prog Cardiovasc Dis. 2007; 50(1): 31-48.

50. Messina E, De Angelis L, Frati G, Morrone S, Chimenti S, Fiordaliso F, Salio M, Battaglia M, Latronico MV, Coletta M, Vivarelli E, Frati L, Cossu G, Giacomello A. Isolation and expansion of adult cardiac stem cells from human and murine heart. Circ Res. 2004; 95(9): 911-921.

51. Chimenti I, Gaetani R, Barile L, Forte E, Ionta V, Angelini F, Frati G, Messina E, Giacomello A. Isolation and expansion of adult cardiac stem/ progenitor cells in the form of cardiospheres from human cardiac biopsies and murine hearts. Methods Mol Biol. 2012; 879: 327-338.

52. Davis DR, Zhang Y, Smith RR, Cheng K, Terrovitis J, Malliaras K, Li TS, White A, Makkar R, Marbán E. Validation of the cardiosphere method to culture cardiac progenitor cells from myocardial tissue. PLoS One. 2009; 4(9): e7195.

53. Davis DR, Kizana E, Terrovitis J, Barth AS, Zhang Y, Smith RR, Miake J, Marbán E. Isolation and expansion of functionally-competent cardiac progenitor cells directly from heart biopsies. J Mol Cell Cardiol. 2010; 49(2): 312-321.

54. Li TS, Cheng K, Lee ST, Matsushita S, Davis D, Malliaras K, Zhang Y, Matsushita N, Smith RR, Marbán E. Cardiospheres recapitulate a nichelike microenvironment rich in stemness and cellmatrix interactions, rationalizing their enhanced functional potency for myocardial repair. Stem Cells. 2010; 28(11): 2088-2098.

55. Smith RR, Barile L, Cho HC, Leppo MK, Hare JM, Messina E, Giacomello A, Abraham MR, Marbán E. Regenerative potential of cardiospherederived cells expanded from percutaneous endomyocardial biopsy specimens. Circulation. 2007; 115(7): 896-908. 
56. Emmert MY. Cell-based cardiac regeneration. Eur Heart J. 2017; 38(15): 1095-1098.

57. Nguyen PK, Rhee JW, Wu JC. Adult Stem Cell Therapy and Heart Failure, 2000 to 2016: A Systematic Review. JAMA Cardiol. 2016; 1(7): 831-841.

58. Li TS, Cheng K, Malliaras K, Smith RR, Zhang Y, Sun B, Matsushita N, Blusztajn A, Terrovitis J, Kusuoka H, Marbán L, Marbán E. Direct comparison of different stem cell types and subpopulations reveals superior paracrine potency and myocardial repair efficacy with cardiosphere-derived cells. J Am Coll Cardiol. 2012; 59(10): 942-953.

59. Johnston PV, Sasano T, Mills K, Evers R, Lee ST, Smith RR, Lardo AC, Lai S, Steenbergen C, Gerstenblith G, Lange R, Marbán E. Engraftment, differentiation, and functional benefits of autologous cardiosphere-derived cells in porcine ischemic cardiomyopathy. Circulation. 2009; 120(12): 1075-1083, 1087 p following 1083.

60. Kanazawa H, Tseliou E, Malliaras K, Yee K, Dawkins JF, De Couto G, Smith RR, Kreke M, Seinfeld J, Middleton RC, Gallet R, Cheng K, Luthringer D, Valle I, Chowdhury S, Fukuda K, Makkar RR, Marbán L, Marbán E. Cellular postconditioning: allogeneic cardiospherederived cells reduce infarct size and attenuate microvascular obstruction when administered after reperfusion in pigs with acute myocardial infarction. Circ Heart Fail. 2015; 8(2): 322-332.

61. Sousonis V, Nanas J, Terrovitis J. Cardiospherederived progenitor cells for myocardial repair following myocardial infarction. Curr Pharm Des. 2014; 20(12): 2003-2011.

62. Kreke M, Smith RR, Marbán L, Marbán E. Cardiospheres and cardiosphere-derived cells as therapeutic agents following myocardial infarction. Expert Rev Cardiovasc Ther. 2012; 10(9): 1185-1194.

63. Malliaras K, Li TS, Luthringer D, Terrovitis J, Cheng K, Chakravarty T, Galang G, Zhang Y, Schoenhoff F, Van Eyk J, Marbán L, Marbán E. Safety and efficacy of allogeneic cell therapy in infarcted rats transplanted with mismatched cardiosphere-derived cells. Circulation. 2012; 125(1): 100-112.

64. Martens A, Gruh I, Dimitroulis D, Rojas SV, Schmidt-Richter I, Rathert C, Khaladj N, Gawol A, Chikobava MG, Martin U, Haverich A, Kutschka I. Rhesus monkey cardiosphere-derived cells for myocardial restoration. Cytotherapy. 2011; 13(7): 864-872.
65. Weil BR, Suzuki G, Leiker MM, Fallavollita JA, Canty JM. Comparative Efficacy of Intracoronary Allogeneic Mesenchymal Stem Cells and Cardiosphere-Derived Cells in Swine with Hibernating Myocardium. Circ Res. 2015; 117(7): 634-644.

66. Makkar RR, Smith RR, Cheng K, Malliaras K, Thomson LE, Berman D, Czer LS, Marbán L, Mendizabal A, Johnston PV, Russell SD, Schuleri KH, Lardo AC, Gerstenblith G, Marbán E. Intracoronary cardiosphere-derived cells for heart regeneration after myocardial infarction (CADUCEUS): a prospective, randomised phase 1 trial. Lancet. 2012; 379(9819): 895-904.

67. Malliaras K, Makkar RR, Smith RR, Cheng $\mathrm{K}$, Wu E, Bonow RO, Marbán L, Mendizabal A, Cingolani E, Johnston PV, Gerstenblith G, Schuleri KH, Lardo AC, Marbán E. Intracoronary cardiosphere-derived cells after myocardial infarction: evidence of therapeutic regeneration in the final 1-year results of the CADUCEUS trial (CArdiosphere-Derived aUtologous stem CElls to reverse ventricUlar dySfunction). J Am Coll Cardiol. 2014; 63(2): 110-122.

68. Chakravarty T, Makkar RR, Ascheim DD, Traverse JH, Schatz R, DeMaria A, Francis GS, Povsic TJ, Smith RR, Lima JA, Pogoda JM, Marbán L, Henry TD. ALLogeneic Heart STem Cells to Achieve Myocardial Regeneration (ALLSTAR) Trial: Rationale and Design. Cell Transplant. 2017; 26(2): 205-214.

69. Malliaras K, Ibrahim A, Tseliou E, Liu W, Sun B, Middleton RC, Seinfeld J, Wang L, Sharifi BG, Marbán E. Stimulation of endogenous cardioblasts by exogenous cell therapy after myocardial infarction. EMBO Mol Med. 2014; 6(6): 760-777.

70. Malliaras K, Zhang Y, Seinfeld J, Galang G, Tseliou E, Cheng K, Sun B, Aminzadeh M, Marbán E. Cardiomyocyte proliferation and progenitor cell recruitment underlie therapeutic regeneration after myocardial infarction in the adult mouse heart. EMBO Mol Med. 2013; 5(2): 191-209.

71. Chimenti I, Smith RR, Li TS, Gerstenblith G, Messina E, Giacomello A, Marbán E. Relative roles of direct regeneration versus paracrine effects of human cardiosphere-derived cells transplanted into infarcted mice. Circ Res. 2010; 106(5): 971-980.

72. Barile L, Lionetti V, Cervio E, Matteucci M, Gherghiceanu M, Popescu LM, Torre T, Siclari F, Moccetti T, Vassalli G. Extracellular vesicles from human cardiac progenitor cells inhibit cardiomyocyte apoptosis and improve cardiac 
function after myocardial infarction. Cardiovasc Res. 2014; 103(4): 530-541.

73. Chen L, Wang Y, Pan Y, Zhang L, Shen C, Qin G, Ashraf M, Weintraub N, Ma G, Tang Y. Cardiac progenitor-derived exosomes protect ischemic myocardium from acute ischemia/reperfusion injury. Biochem Biophys Res Commun. 2013; 431(3): 566-571.

74. Vandergriff AC, de Andrade JB, Tang J, Hensley MT, Piedrahita JA, Caranasos TG, Cheng K. Intravenous Cardiac Stem Cell-Derived Exosomes Ameliorate Cardiac Dysfunction in Doxorubicin Induced Dilated Cardiomyopathy. Stem Cells Int. 2015; 2015: 960926.

75. Witman N, Sahara M. Cardiac Progenitor Cells in Basic Biology and Regenerative Medicine. Stem Cells Int. 2018; 2018: 8283648.

76. Martinez EC, Kofidis T. Myocardial tissue engineering: the quest for the ideal myocardial substitute. Expert Rev Cardiovasc Ther. 2009; 7(8): 921-928.

77. Yi S, Ding F, Gong L, Gu X. Extracellular Matrix Scaffolds for Tissue Engineering and Regenerative Medicine. Curr Stem Cell Res Ther. 2017; 12(3): 233-246.

78. He Y, Lu F. Development of Synthetic and Natural Materials for Tissue Engineering Applications Using Adipose Stem Cells. Stem Cells Int. 2016; 2016: 5786257.

79. Rodrigues ICP, Kaasi A, Maciel Filho R, Jardini AL, Gabriel LP. Cardiac tissue engineering: current state-of-the-art materials, cells and tissue formation. Einstein (Sao Paulo). 2018; 16(3): eRB4538.

80. Dziki JL, Badylak SF. Extracellular Matrix for Myocardial Repair. Adv Exp Med Biol. 2018; 1098: 151-171.

81. Hong $\mathrm{Y}$, Huber A, Takanari K, Amoroso NJ, Hashizume R, Badylak SF, Wagner WR. Mechanical properties and in vivo behavior of a biodegradable synthetic polymer microfiberextracellular matrix hydrogel biohybrid scaffold. Biomaterials. 2011; 32(13): 3387-3394.

82. Kargozar S, Hamzehlou S, Baino F. Potential of Bioactive Glasses for Cardiac and Pulmonary Tissue Engineering. Materials (Basel). 2017; 10(12): pii: E1429.

83. Hench LL, Splinter RJ, Allen WC, Greenlee TK. Bonding mechanisms at the interface of ceramic prosthetic materials. J Biomed Mater Res. 1971; 5(6): 117-141.

84. Barabadi Z, Azami M, Sharifi E, Karimi R, Lotfibakhshaiesh N, Roozafzoon R, Joghataei MT,
Ai J. Fabrication of hydrogel based nanocomposite scaffold containing bioactive glass nanoparticles for myocardial tissue engineering. Mater Sci Eng C Mater Biol Appl. 2016; 69: 1137-1146.

85. Song JJ, Ott HC. Organ engineering based on decellularized matrix scaffolds. Trends Mol Med. 2011; 17(8): 424-432.

86. Taylor DA, Sampaio LC, Ferdous Z, Gobin AS, Taite LJ. Decellularized matrices in regenerative medicine. Acta Biomater. 2018; 74: 74-89.

87. Seo Y, Jung Y, Kim SH. Decellularized heart ECM hydrogel using supercritical carbon dioxide for improved angiogenesis. Acta Biomater. 2018; 67: 270-281.

88. Fu RH, Wang YC, Liu SP, Shih TR, Lin HL, Chen YM, Sung JH, Lu CH, Wei JR, Wang ZW, Huang SJ, Tsai CH, Shyu WC, Lin SZ. Decellularization and recellularization technologies in tissue engineering. Cell Transplant. 2014; 23(4-5): 621-630.

89. Keane TJ, Swinehart IT, Badylak SF. Methods of tissue decellularization used for preparation of biologic scaffolds and in vivo relevance. Methods. 2015; 84: 25-34.

90. Badylak SF, Taylor D, Uygun K. Whole-organ tissue engineering: decellularization and recellularization of three-dimensional matrix scaffolds. Annu Rev Biomed Eng. 2011; 13: 27-53.

91. Wang RM, Johnson TD, He J, Rong Z, Wong $\mathrm{M}$, Nigam V, Behfar A, Xu Y, Christman KL. Humanized mouse model for assessing the human immune response to xenogeneic and allogeneic decellularized biomaterials. Biomaterials. 2017; 129: 98-110.

92. Chen WC, Wang Z, Missinato MA, Park DW, Long DW, Liu HJ, Zeng X, Yates NA, Kim $\mathrm{K}$, Wang $\mathrm{Y}$. Decellularized zebrafish cardiac extracellular matrix induces mammalian heart regeneration. Sci Adv. 2016; 2(11): e1600844.

93. Heuschkel MA, Leitolis A, Roderjan JG, Suss $\mathrm{PH}$, Luzia CAO, da Costa FDA, Correa A, Stimamiglio MA. In vitro evaluation of bovine pericardium after a soft decellularization approach for use in tissue engineering. Xenotransplantation. Epub 2018 Sep 28.

94. Mallis P, Michalopoulos E, Dimitriou C, Kostomitsopoulos N, Stavropoulos-Giokas C. Histological and biomechanical characterization of decellularized porcine pericardium as a potential scaffold for tissue engineering applications. Biomed Mater Eng. 2017; 28(5): 477-488.

95. Spinali KL, Schmuck EG. Natural Sources of Extracellular Matrix for Cardiac Repair. Adv Exp Med Biol. 2018; 1098: 115-130. 
96. Scholl FG, Boucek MM, Chan KC, Valdes-Cruz L, Perryman R. Preliminary experience with cardiac reconstruction using decellularized porcine extracellular matrix scaffold: human applications in congenital heart disease. World $\mathrm{J}$ Pediatr Congenit Heart Surg. 2010; 1(1): 132-136.

97. Badylak SF, Kochupura PV, Cohen IS, Doronin SV, Saltman AE, Gilbert TW, Kelly DJ, Ignotz RA, Gaudette GR. The use of extracellular matrix as an inductive scaffold for the partial replacement of functional myocardium. Cell Transplant. 2006; 15 Suppl 1: S29-S40.

98. Wainwright JM, Hashizume R, Fujimoto KL, Remlinger NT, Pesyna C, Wagner WR, Tobita K, Gilbert TW, Badylak SF. Right ventricular outflow tract repair with a cardiac biologic scaffold. Cells Tissues Organs. 2012; 195(1-2): 159-170.

99. Eitan Y, Sarig U, Dahan N, Machluf M. Acellular cardiac extracellular matrix as a scaffold for tissue engineering: in vitro cell support, remodeling, and biocompatibility. Tissue Eng Part C Methods. 2010; 16(4): 671-683.

100. Oberwallner B, Brodarac A, Choi YH, Saric T, Anić P, Morawietz L, Stamm C. Preparation of cardiac extracellular matrix scaffolds by decellularization of human myocardium. J Biomed Mater Res A. 2014; 102(9): 3263-3272.

101. Di Meglio F, Nurzynska D, Romano V, Miraglia R, Belviso I, Sacco AM, Barbato V, Di Gennaro M, Granato G, Maiello C, Montagnani S, Castaldo C. Optimization of Human Myocardium Decellularization Method for the Construction of Implantable Patches. Tissue Eng Part C Methods. 2017; 23(9): 525-539.

102. Hoit BD. Anatomy and Physiology of the Pericardium. Cardiol Clin. 2017; 35(4): 481-490.

103. Nguyen-Truong M, Wang Z. Biomechanical Properties and Mechanobiology of Cardiac ECM. Adv Exp Med Biol. 2018; 1098: 1-19.

104. Gattazzo F, Urciuolo A, Bonaldo P. Extracellular matrix: a dynamic microenvironment for stem cell niche. Biochim Biophys Acta. 2014; 1840(8): 2506-2519.

105. Mauretti A, Spaans S, Bax NAM, Sahlgren C, Bouten CVC. Cardiac Progenitor Cells and the Interplay with Their Microenvironment. Stem Cells Int. 2017; 2017: 7471582.

106. Taylor PM, Allen SP, Dreger SA, Yacoub MH. Human cardiac valve interstitial cells in collagen sponge: a biological three-dimensional matrix for tissue engineering. J Heart Valve Dis. 2002; 11(3): 298-306; discussion 306-307.
107. Chimenti I, Rizzitelli G, Gaetani R, Angelini F, Ionta V, Forte E, Frati G, Schussler O, Barbetta A, Messina E, Dentini M, Giacomello A. Human cardiosphere-seeded gelatin and collagen scaffolds as cardiogenic engineered bioconstructs. Biomaterials. 2011; 32(35): 9271-9281.

108. Boffito M, Di Meglio F, Mozetic P, Giannitelli SM, Carmagnola I, Castaldo C, Nurzynska D, Sacco AM, Miraglia R, Montagnani S, Vitale N, Brancaccio M, Tarone G, Basoli F, Rainer A, Trombetta M, Ciardelli G, Chiono V. Surface functionalization of polyurethane scaffolds mimicking the myocardial microenvironment to support cardiac primitive cells. PLoS One. 2018; 13(7): e0199896.

109. Wang X, Ali MS, Lacerda CMR. A ThreeDimensional Collagen-Elastin Scaffold for Heart Valve Tissue Engineering. Bioengineering (Basel). 2018; 5(3): pii: E69.

110. Esmaeili Pourfarhangi K, Mashayekhan S, Asl SG, Hajebrahimi Z. Construction of scaffolds composed of acellular cardiac extracellular matrix for myocardial tissue engineering. Biologicals. 2018; 53: 10-18.

111. Sánchez PL, Fernández-Santos ME, Costanza S, Climent AM, Moscoso I, Gonzalez-Nicolas MA, Sanz-Ruiz R, Rodríguez H, Kren SM, Garrido G, Escalante JL, Bermejo J, Elizaga J, Menarguez J, Yotti R, Pérez del Villar C, Espinosa MA, Guillem MS, Willerson JT, Bernad A, Matesanz R, Taylor DA, Fernández-Avilés F. Acellular human heart matrix: A critical step toward whole heart grafts. Biomaterials. 2015; 61: 279-289.

112. Sarig U, Sarig $H$, de-Berardinis E, Chaw SY, Nguyen EB, Ramanujam VS, Thang VD, AlHaddawi M, Liao S, Seliktar D, Kofidis T, Boey FY, Venkatraman SS, Machluf M. Natural myocardial ECM patch drives cardiac progenitor based restoration even after scarring. Acta Biomater. 2016; 44: 209-220.

113. Daley MC, Fenn SL, Black LD. Applications of Cardiac Extracellular Matrix in Tissue Engineering and Regenerative Medicine. Adv Exp Med Biol. 2018; 1098: 59-83.

114. Castaldo C, Chimenti I. Cardiac Progenitor Cells: The Matrix Has You. Stem Cells Transl Med. 2018; 7(7): 506-510.

115. Svystonyuk DA, Mewhort HEM, Fedak PWM. Using Acellular Bioactive Extracellular Matrix Scaffolds to Enhance Endogenous Cardiac Repair. Front Cardiovasc Med. 2018; 5: 35. 
116. Rajabi-Zeleti S, Jalili-Firoozinezhad S, Azarnia M, Khayyatan F, Vahdat S, Nikeghbalian S, et al. The behavior of cardiac progenitor cells on macroporous pericardium-derived scaffolds. Biomaterials. 2014; 35(3): 970-982.

117. Li X, Tamama K, Xie X, Guan J. Improving Cell Engraftment in Cardiac Stem Cell Therapy. Stem Cells Int. 2016; 2016: 7168797.

118. Pal A, Vernon BL, Nikkhah M. Therapeutic neovascularization promoted by injectable hydrogels. Bioact Mater. 2018; 3(4): 389-400.

119. Tous E, Purcell B, Ifkovits JL, Burdick JA. Injectable acellular hydrogels for cardiac repair. J Cardiovasc Transl Res. 2011; 4(5): 528-542.

120. Ahmed EM. Hydrogel: Preparation, characterization, and applications: A review. J Adv Res. 2015; 6(2): 105-121.

121. Christman KL, Vardanian AJ, Fang Q, Sievers RE, Fok HH, Lee RJ. Injectable fibrin scaffold improves cell transplant survival, reduces infarct expansion, and induces neovasculature formation in ischemic myocardium. J Am Coll Cardiol. 2004; 44(3): 654-660.

122. Gaetani R, Yin C, Srikumar N, Braden R, Doevendans PA, Sluijter JP, Christman KL. Cardiac-Derived Extracellular Matrix Enhances Cardiogenic Properties of Human Cardiac Progenitor Cells. Cell Transplant. 2016; 25(9): 1653-1663.

123. Singelyn JM, Sundaramurthy $P$, Johnson TD, Schup-Magoffin PJ, Hu DP, Faulk DM, Wang J, Mayle KM, Bartels K, Salvatore M, Kinsey AM, Demaria AN, Dib N, Christman KL. Catheterdeliverable hydrogel derived from decellularized ventricular extracellular matrix increases endogenous cardiomyocytes and preserves cardiac function post-myocardial infarction. J Am Coll Cardiol. 2012; 59(8): 751-763.

124. Seif-Naraghi SB, Singelyn JM, Salvatore MA, Osborn KG, Wang JJ, Sampat U, Kwan OL, Strachan GM, Wong J, Schup-Magoffin PJ, Braden RL, Bartels K, DeQuach JA, Preul M, Kinsey AM, DeMaria AN, Dib N, Christman KL. Safety and efficacy of an injectable extracellular matrix hydrogel for treating myocardial infarction. Sci TransI Med. 2013; 5(173): 173ra25.

125. Wassenaar JW, Gaetani R, Garcia JJ, Braden RL, Luo CG, Huang D, DeMaria AN, Omens $\mathrm{JH}$, Christman KL. Evidence for Mechanisms Underlying the Functional Benefits of a Myocardial Matrix Hydrogel for Post-MI Treatment. J Am Coll Cardiol. 2016; 67(9): 1074-1086.
126. Zhu Y, Matsumura Y, Wagner WR. Ventricular wall biomaterial injection therapy after myocardial infarction: Advances in material design, mechanistic insight and early clinical experiences. Biomaterials. 2017; 129: 37-53.

127. Saldin LT, Cramer MC, Velankar SS, White LJ, Badylak SF. Extracellular matrix hydrogels from decellularized tissues: Structure and function. Acta Biomater. 2017; 49: 1-15.

128. Oberwallner B, Brodarac A, Anić P, Šarić T, Wassilew K, Neef K, Choi YH, Stamm C. Human cardiac extracellular matrix supports myocardial lineage commitment of pluripotent stem cells. Eur J Cardiothorac Surg. 2015; 47(3): 416-425; discussion 425.

129. Kappler B, Anic P, Becker M, Bader A, Klose K, Klein O, Oberwallner B, Choi YH, Falk V, Stamm C. The cytoprotective capacity of processed human cardiac extracellular matrix. J Mater Sci Mater Med. 2016; 27(7): 120.

130. Johnson TD, Dequach JA, Gaetani R, Ungerleider J, Elhag D, Nigam V, Behfar A, Christman KL. Human versus porcine tissue sourcing for an injectable myocardial matrix hydrogel. Biomater Sci. 2014; 2014: 60283D.

131. Valiente-Alandi I, Schafer AE, Blaxall BC. Extracellular matrix-mediated cellular communication in the heart. J Mol Cell Cardiol. 2016; 91: 228-237.

132. Saludas L, Pascual-Gil S, Prósper F, Garbayo E, Blanco-Prieto M. Hydrogel based approaches for cardiac tissue engineering. Int J Pharm. 2017; 523(2): 454-475.

133. Frey N, Linke A, Süselbeck T, Müller-Ehmsen J, Vermeersch P, Schoors D, Rosenberg M, Bea F, Tuvia S, Leor J. Intracoronary delivery of injectable bioabsorbable scaffold (IK-5001) to treat left ventricular remodeling after ST-elevation myocardial infarction: a first-in-man study. Circ Cardiovasc Interv. 2014; 7(6): 806-812.

134. Rao SV, Zeymer U, Douglas PS, Al-Khalidi H, White JA, Liu J, Levy H, Guetta V, Gibson CM, Tanguay JF, Vermeersch P, Roncalli J, Kasprzak JD, Henry TD, Frey N, Kracoff O, Traverse JH, Chew DP, Lopez-Sendon J, Heyrman R, Krucoff MW. Bioabsorbable Intracoronary Matrix for Prevention of Ventricular Remodeling After Myocardial Infarction. J Am Coll Cardiol. 2016; 68(7): 715-723.

135. Garcia JR, Campbell PF, Kumar G, Langberg JJ, Cesar L, Deppen JN, Shin EY, Bhatia NK, Wang L, Xu K, Schneider F, Robinson B, García 
AJ, Levit RD. Minimally Invasive Delivery of Hydrogel-Encapsulated Amiodarone to the Epicardium Reduces Atrial Fibrillation. Circ Arrhythm Electrophysiol. 2018; 11(5): e006408.

136. Zhang J, Wu Z, Fan Z, Qin Z, Wang Y, Chen J, Wu M, Chen Y, Wu C, Wang J. Pericardial application as a new route for implanting stem-cell cardiospheres to treat myocardial infarction. J Physiol. 2018; 596(11): 2037-2054.

137. Ozbolat IT, Yu Y. Bioprinting toward organ fabrication: challenges and future trends. IEEE Trans Biomed Eng. 2013; 60(3): 691-699.

138. Mir TA, Nakamura M. Three-Dimensional Bioprinting: Toward the Era of Manufacturing Human Organs as Spare Parts for Healthcare and Medicine<sup/>. Tissue Eng Part B Rev. 2017; 23(3): 245-256.

139. Hospodiuk M, Dey M, Sosnoski D, Ozbolat IT. The bioink: A comprehensive review on bioprintable materials. Biotechnol Adv. 2017; 35(2): 217-239.

140. Seol YJ, Kang HW, Lee SJ, Atala A, Yoo JJ. Bioprinting technology and its applications. Eur J Cardiothorac Surg. 2014; 46(3): 342-348.

141. Aljohani W, Ullah MW, Zhang X, Yang G. Bioprinting and its applications in tissue engineering and regenerative medicine. Int $\mathrm{J}$ Biol Macromol. 2018; 107(Pt A): 261-275.

142. Duan B, Kapetanovic E, Hockaday LA, Butcher JT. Three-dimensional printed trileaflet valve conduits using biological hydrogels and human valve interstitial cells. Acta Biomater. 2014; 10(5): 1836-1846.

143. Thomas M, Willerth SM. 3-D Bioprinting of Neural Tissue for Applications in Cell Therapy and Drug Screening. Front Bioeng Biotechnol. 2017; 5: 69.

144. Gungor-Ozkerim PS, Inci I, Zhang YS, Khademhosseini A, Dokmeci MR. Bioinks for 3D bioprinting: an overview. Biomater Sci. 2018; 6(5): 915-946.

145. Liu X, Zuo Y, Sun J, Guo Z, Fan H, Zhang X. Degradation regulated bioactive hydrogel as the bioink with desirable moldability for microfluidic biofabrication. Carbohydr Polym. 2017; 178: 8-17.

146. Skardal A, Devarasetty M, Kang HW, Mead I, Bishop C, Shupe T, Lee SJ, Jackson J, Yoo J, Soker S, Atala A. A hydrogel bioink toolkit for mimicking native tissue biochemical and mechanical properties in bioprinted tissue constructs. Acta Biomater. 2015; 25: 24-34.
147. Akkouch A, Yu Y, Ozbolat IT. Microfabrication of scaffold-free tissue strands for three-dimensional tissue engineering. Biofabrication. 2015; 7(3): 031002.

148. Yu Y, Moncal KK, Li J, Peng W, Rivero I, Martin JA, Ozbolat IT. Three-dimensional bioprinting using self-assembling scalable scaffold-free "tissue strands" as a new bioink. Sci Rep. 2016; 6: 28714.

149. Toprakhisar B, Nadernezhad A, Bakirci E, Khani N, Skvortsov GA, Koc B. Development of Bioink from Decellularized Tendon Extracellular Matrix for 3D Bioprinting. Macromol Biosci. 2018; 18(10): e1800024.

150. Cui H, Miao S, Esworthy T, Zhou X, Lee SJ, Liu C, Yu ZX, Fisher JP, Mohiuddin M, Zhang LG. 3D bioprinting for cardiovascular regeneration and pharmacology. Adv Drug Deliv Rev. 2018; 132: 252-269.

151. Datta P, Barui A, Wu Y, Ozbolat V, Moncal KK, Ozbolat IT. Essential steps in bioprinting: From pre- to post-bioprinting. Biotechnol Adv. 2018; 36(5): 1481-1504.

152. Gudapati H, Dey M, Ozbolat I. A comprehensive review on droplet-based bioprinting: Past, present and future. Biomaterials. 2016; 102: 20-42.

153. Leberfinger AN, Ravnic DJ, Dhawan A, Ozbolat IT. Concise Review: Bioprinting of Stem Cells for Transplantable Tissue Fabrication. Stem Cells Transl Med. 2017; 6(10): 1940-1948.

154. Ozbolat IT, Hospodiuk M. Current advances and future perspectives in extrusion-based bioprinting. Biomaterials. 2016; 76: 321-343.

155. Gaetani R, Feyen DA, Verhage V, Slaats $R$, Messina $E$, Christman KL, Giacomello A, Doevendans PA, Sluijter JP. Epicardial application of cardiac progenitor cells in a 3D-printed gelatin/hyaluronic acid patch preserves cardiac function after myocardial infarction. Biomaterials. 2015; 61: 339-348.

156. Wang Z, Lee SJ, Cheng HJ, Yoo JJ, Atala A. 3D bioprinted functional and contractile cardiac tissue constructs. Acta Biomater. 2018; 70: 48-56.

157. Ong CS, Fukunishi T, Nashed A, Blazeski A, Zhang H, Hardy S, DiSilvestre D, Vricella L, Conte J, Tung L, Tomaselli G, Hibino N. Creation of Cardiac Tissue Exhibiting Mechanical Integration of Spheroids Using 3D Bioprinting. J Vis Exp. 2017; (125): e55438. doi: 10.3791/55438.

158. Jana S, Lerman A. Bioprinting a cardiac valve. Biotechnol Adv. 2015; 33(8): 1503-1521. 
159. Cheung DY, Duan B, Butcher JT. Current progress in tissue engineering of heart valves: multiscale problems, multiscale solutions. Expert Opin Biol Ther. 2015; 15(8): 1155-1172.

160. Kang LH, Armstrong PA, Lee LJ, Duan B, Kang $\mathrm{KH}$, Butcher JT. Optimizing Photo-Encapsulation Viability of Heart Valve Cell Types in 3D
Printable Composite Hydrogels. Ann Biomed Eng. 2017; 45(2): 360-377.

161. Zhang S, Wang H. Current Progress in 3D Bioprinting of Tissue Analogs. SLAS Technol. 2018. doi: $10.1177 / 2472630318799971$.

162. Xia Z, Jin S, Ye K. Tissue and Organ 3D Bioprinting. SLAS Technol. 2018; 23(4): 301-314. 